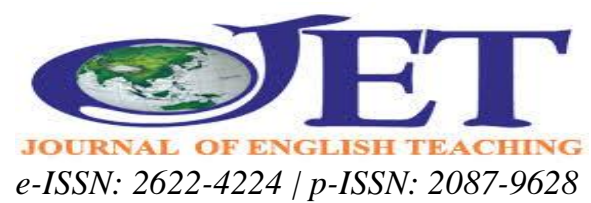

\title{
English Pre-service Teachers' Perception of Anxiety in Peer Teaching: A Case Study at Universitas Kristen Indonesia
}

\author{
Veronica Novembrin Maulimora \\ veronica.nm911@gmail.com \\ English Education Department, \\ Universitas Kristen Indonesia
}

DOI: http://dx.doi.org/10.33541/jet.v5i3.1307

\begin{abstract}
Anxieties that are experienced by the teachers are also undergone by the pre-service teachers. The pre-service teachers feel anxious when they teach students or their peers in a real classroom. This study aimed at investigating English pre-service teachers' perceptions of anxiety in peer teaching. To achieve the objective, a questionnaire and open-ended questions were administered to gauge the perceptions of 44 pre-service teachers of the English Education Department, Faculty of Education and Teacher Training, Universitas Kristen Indonesia. Findings revealed that the majority of the preservice English teachers felt anxious about their first peer teaching practice. It was shown that pre-service teachers were unconfident; worried about their English language skills, teaching skills, evaluation skills, and classroom management; and were not sure of the preparations they had made. The top factor causing their anxiety was their classroom management skills. This means that they put the greatest concern on the way they would manage the class. Nevertheless, by knowing the causes of the anxiety, they got the opportunities to reduce it in the next teaching.
\end{abstract}

Keywords: peer teaching; perception; pre-service teachers, teacher's anxiety,

\section{INTRODUCTION}

Pre-service teachers are the ones who study in a teacher-training program for serving in domestic public schools or international educational institutions after obtaining teaching accreditation (Lee, 2019). Pre-service teachers face many states of affairs as they try to accomplish magnificence. Not only to prove that they master the subject matter, but they also have to show their best at managing classrooms, teaching with proper methods, and assessing their students. When pre-service teachers also choose to take the teaching degree in English as a foreign language class, the difficulty of acquiring nearnative fluency is added (Kfouri, 2013). One of the hurdles that pre-service teachers must face is teaching practice. Teaching practice is an essential part of becoming a real teacher. It gives student-teacher experience in actual teaching and learning situations (Ngidi \& Sibaya, 2003). Teaching practice also creates a combination of anticipation, 
anxiety, excitement, and apprehensiveness in the student teachers as they start their teaching practice (Manion, et.al, 2003).

The anxiety of teachers is one of many disquiets that is experienced not only by the teachers but also something that pre-service teachers have to face. The negative effects of anxiety have strong causation of the teaching performance that pre-service teachers experience, especially in the first face-to-face meeting with students. Anxiety in this specific meaning is an uneasy feeling of tension or fear about something that is going to happen or something that might be happening in the future (Cambridge, 2012).

Many language teachers who are not native speakers experience anxiety in their language classrooms (Horwitz, 1986). In this case, pre-service English teachers might also experience difficulties during the teaching practice because of their lack of experience in using the target language. For example, they may feel worried or shy speaking the foreign language in the classroom.

Kim and Kim (2004) discovered that the most anxious situations that were experienced by the pre-service English teachers were when they teach English through English, when students ask questions, when they teach speaking and listening skills, when the students are not motivated and when they cannot be controlled, and when they are observed by someone while teaching. Another study by Yuksel (2008) found out that the highest concern to pre-service teachers was when they have to teach English skills such as grammar, listening and speaking.

As the discussion above shows, some studies have investigated anxieties experienced by pre-service teachers in teaching practice in real classrooms. However, the anxiety experienced by the pre-service teachers in peer teaching in their microteaching class has never been studied, whereas peer teaching is "extremely effective for a wide range of goals, content, and students of different levels and personalities" (McKeachie et al., 1986). Since peer teaching engages a student to teach other students in a particular subject area, anxiety will also likely to occur. By identifying and understanding such anxiety, students can prepare him or her better. One's success in peer teaching, in turn, can prepare him/her to do well in the teaching practice program he/she will take. Whitman (1998) accentuated, that "to teach is to learn twice', meaning that peer teaching is experienced by pre-service teachers before they start the teaching practice in schools. With the background above, this study was conducted to explore pre-service English teachers' perceptions of anxiety in peer teaching.

\section{LITERATURE REVIEW}

\section{What are Pre-service Teachers and Anxiety?}

Johnson and Perry (1967) stated that pre-service teachers refer to college students who are engaged in an assigned student teaching experience. Also, Ivanova and SkaraMincāne (2016) said that pre-service teachers are teacher candidates who are necessarily needed to form their professional identities that are shaped during their studying period, especially through courses related to teaching and pedagogy. The college students or the pre-service teachers learn how to teach for they are future teachers. Pre-service teachers are also given the chance to challenge themselves to teach their students in any method or technique. The first face-to-face meeting is a challenging experience for pre-service teachers that meet and teach new students.

In some universities, for example, Universitas Kristen Indonesia, to prepare the pre-service teachers to enter the real teaching world, they have to take a micro-teaching class. It is the first teaching practice that they experience. This teaching practice takes 
their peers as students. In the peer teaching practice, the pre-service teachers are supervised by their micro-teaching lecturer. They are also observed by their peers to give comments and suggestions for their teaching practice.

Anxiety is experienced by a person who gets worried because of a situation that does not give a clear answer, or when he cannot expect anything for help so that he seems to have no clear hope. Anxiety and worry are lightweight and become motivation (Sukmadinata, 2004). Additionally, Scovel (1991) described anxiety as a state of uneasiness and apprehensiveness or concern that is caused by the anticipation of something threatening.

\section{Teachers' Anxiety}

The study of Randall and Thornton (2001) found that anxiety can be a positive influence on teachers if it is at the right scale. They also admitted that some teachers feel nervous before encountering a class, so they aimed to arrange and align effective lessons for their class, and pay close attention to what is happening in the class. In 1978, Moskowitz found out the cause of the anxiety experienced by teachers. It is caused by fear, and that fear might make teachers do any possible damage to students unintentionally.

The study of Kongchan and Singhasiri (2008) proved that anxiety can also relate to expectations, this means that a person can have anxiety when what they expected to happen is not happening. The level of the anxiety that is found was varied. One of them is when teachers expected to teach the students whose English proficiency was high, but in fact, the teachers had to teach low English proficient students. The effect of this kind of unexpectedness caused those teachers to worry about using English to instruct the students. Moreover, the teachers were worried because the students did not get what the teachers said in English and it made teachers confused whether they should continue speaking English or not.

Perry (2004), in his research topic about tensions of teacher educators in learning about their own practice and tasks in school contexts categorized the causes of teachers' anxiety into six categories; telling and growth (giving a chance to self- reflect and accepting student teachers' concerns in developing ability), confidence and uncertainty, working with and against, discomfort and challenge, acknowledging and building upon experience, and the last, planning and being responsive. In this study, he focused on the teachers' anxiety that occurred when the teachers practiced their profession in the school contexts. In addition, Randall and Thornton (2001) found out five categories of the factors that affected anxiety of teachers in teaching supervision contexts: evaluation (getting feedback and a grade from an advisor), novelty (facing with a new situation), ambiguity (having an ambiguous situation), conspicuousness (being a more noticeable teacher), and prior history (confronting with the same anxious situation). These studies set various categories of the causes of teachers' anxiety, depending on different perspectives of teaching and learning.

\section{Pre-service Teachers' Anxiety}

The first meeting is a certainly difficult experience for pre-service teachers to meet with and teach students for their first time. That is, the expectation of what they are going to do can be affected by their anxiety, an anxiety that showed up even before the class starts. Besides, the teachers feel disquieted when they have insufficient time to make the lesson plan (Howarth, 2002). Kim \& Kim (2004), they found out the most anxious 
situations for pre-service teachers were as follows: when they have to teach English through English; when students asked unexpected questions, when they teach speaking skill, when students are not motivated or are not interested in their English classes, when the students cannot be controlled, when they have to teach students who have lived in English-speaking countries, when their English classes is observed by someone, when they teach the listening skill, and when they teach English culture.

In 2008, Yuksel investigated the pre-service language teachers' anxiety related to their language learning anxiety. The data analysis showed that anxiety was experienced by the pre-service English teachers on a scale between rarely to sometimes. The highest concern to pre-service teachers was when they were teaching particular language skills such as grammar, listening or speaking skills.

Sameephet and Wanphet (2013) found out some causes of anxiety and grouped them into four categories according to Murray-Harvey categories (1999): teachers' personality, teaching context, supervision context, and others. Another important finding was that there were successful anxiety management techniques; 'self-control', 'let-it-be', and 'face-it and handle-it. Pasaribu \& Herendita (2018), in their study that discussed English language anxiety of pre-service teachers, found out that there were three main reasons for the anxiety that was experienced by pre-service teachers. The first was English language skills. It turned out that pre-service teachers were anxious about their skills in English. They were worried if they had to explain some grammar lessons. The second was the evaluation. Pre-service teachers were afraid if their teaching was not good and could not meet with their lecturer's expectations. The last was preparation. Pre-service teachers were so worried about their preparation. They were not confident enough to teach if they did not prepare very well. This reason was the highest concern for the anxiety that was experienced by pre-service teachers.

\section{Peer Teaching}

Isasiw and Goldenberg (1993) stated that peer teaching means that student mentoring and instructing other students. "The act of peer teaching implies that there is also a peer in the role of a learner. Furthermore, the roles of teacher and learner are often fluid, with students changing roles throughout the teaching and learning process."

The idea of peer teaching is supported by three essential perspectives; cognitive approach, motivational, and social context. According to Svinicki (1991), the first perspective is the cognitive approach, which focuses on strategies of information processing. Learning is maximized when students act on information in ways that make it more meaningful, such as organizing it, making their connections with it, and applying it to new contexts. An example is for students to actively work with course material and discovering ways of conveying it to their classmates. The second perspective, motivational theory, is concerned with how learning is "initiated and sustained"; it advocates giving "responsibility for learning back to the students," and using innovative methods (Forsyth and McMillan, 1991). And the third perspective, social context, the kind of environment most conducive to learning is thought to be "dialogue," characterized by interaction and cooperation. Teachers need to share responsibility for the course with students: give them a say in the details of the syllabus or permit them to "plan certain segments of the course, to make class presentations under (the teacher's) guidance, or to suggest and arrange for discussion topics, etc." (Billson and Tiberius, 1991) 


\section{METHOD}

This study used a mixed-method design that combines both quantitative and qualitative data collection and analysis. They type employed was the explanatory sequential mixed methods design, which starts with quantitative data collection and continues with qualitative data collection aimed to elaborate on the previously obtained quantitative results (Pardede, 2018). The quantitative data were collected using a questionnaire and the qualitative data were obtained through an interview. The population was 6th and 8th-semester students of English Education Department of Universitas Kristen Indonesia in the academic year 2018-2019. The researcher took 44 respondents as the informants of the questionnaire and 5 respondents of open-ended questions. All of the participants have experienced peer teaching in their micro-teaching class.

Data were collected by distributing the questionnaire and interviewing the participants. The questionnaire used to collect the quantitative data was adapted from the instrument by Pasaribu and Herendita (2018) and was modified by the researcher to address the research question. The reliability of the questionnaire was tested by the researcher using Cronbach's Alpha Test. The result showed that Cronbach's Alpha Coefficient of the questionnaire is indicating a high degree of internal consistency $(\mathrm{r}=0.899)$. Thus, it is considered as a reliable instrument. The questionnaire contained 35 questions consisting of seven indicators; pre-service teachers' confidence, English language skills, preparation, lesson delivery, the condition of the peers, evaluations, and classroom management.

The questionnaire was created in Google Form and was responded online by the respondents. The respondents were asked to indicate their agreement or disagreement with each statement that ranged from strongly disagree (score 4), disagree (score 3), agree (score 2) and strongly agree (score 1). For the interview, a semi-structured openended interview that involved five participants was conducted to get more detailed information related to pre-service English teachers' anxiety. To analyze the quantitative data, the descriptive statistical operation in terms of percentages and means was administered.

\section{FINDINGS AND DISCUSSION}

\section{English Pre-service Teachers' Confidence in Peer Teaching}

The findings indicate that most of the pre-service English teachers did not feel confident and sure to handle their teaching practice. Among the five statements in Table 1, two represent anxiety and nervousness. The mean score for getting nervous is 2.70 and feeling shy when speaking English is 2.57. The rest of the statements show that the participants did not feel comfortable in speaking English $(\mathrm{M}=2.64)$, did not feel very sure and relaxed when going to English class $(\mathrm{M}=2.84)$, and did not feel confident to speak in the class $(\mathrm{M}=2.50)$.

These findings show the participants did not feel confident enough to teach. They also agreed that they had high expectations while teaching. This was in line with what Sameephet and Wanphet (2013) found in their study that "anxiety can relate to expectations". In the interview, the participants said that preparing all the things, including the materials made them more confident in teaching. As shown in the following excerpts, a good preparation tended to make them a bit more confident.

"I prepared all things 'cause I know teaching confidence comes from good preparation, especially knowing the topic and the students" (Interviewee A). 
"The thing that made me confident while teaching was preparation, because I believe that even though I'm not 100\% confident in front of the class, well preparation could make me more confident" (Interviewee B).

Table 1:

Perceptions of English Pre-service Teachers' Confidence in Peer Teaching

\begin{tabular}{|c|c|c|c|c|c|c|}
\hline No. & Statements & $\begin{array}{c}\text { SA } \\
F(\%)\end{array}$ & $\begin{array}{c}\text { A } \\
F(\%)\end{array}$ & $\begin{array}{c}\text { D } \\
F(\%)\end{array}$ & $\begin{array}{c}\text { SD } \\
\mathrm{F}(\%)\end{array}$ & Mean \\
\hline 1. & $\begin{array}{l}\text { Did not get nervous when speaking in the } \\
\text { classroom. }\end{array}$ & $\begin{array}{l}0 \\
(0)\end{array}$ & $\begin{array}{c}17 \\
(38.64)\end{array}$ & $\begin{array}{c}23 \\
(52.23)\end{array}$ & $\begin{array}{c}4 \\
(9.10)\end{array}$ & 2.70 \\
\hline 2. & $\begin{array}{l}\text { Did not feel shy when speaking English in } \\
\text { front of students. }\end{array}$ & $\begin{array}{c}3 \\
(6.82)\end{array}$ & $\begin{array}{c}16 \\
(36.36)\end{array}$ & $\begin{array}{c}22 \\
(50)\end{array}$ & $\begin{array}{c}3 \\
(6.82)\end{array}$ & 2.57 \\
\hline 3. & $\begin{array}{l}\text { Didn't feel very comfortable in speaking } \\
\text { English. }\end{array}$ & $\begin{array}{c}0 \\
(0)\end{array}$ & $\begin{array}{c}17 \\
(38.64)\end{array}$ & $\begin{array}{c}26 \\
(59.10)\end{array}$ & $\begin{array}{c}1 \\
(2.27)\end{array}$ & 2.64 \\
\hline 4. & $\begin{array}{l}\text { Didn't feel very sure and relaxed when on } \\
\text { the way to language class. }\end{array}$ & $\begin{array}{c}0 \\
(0)\end{array}$ & $\begin{array}{c}12 \\
(27.27)\end{array}$ & $\begin{array}{c}27 \\
(61.36)\end{array}$ & $\begin{array}{c}5 \\
(11.36)\end{array}$ & 2.84 \\
\hline 5. & $\begin{array}{l}\text { Never felt quite sure when speaking in the } \\
\text { class. }\end{array}$ & $\begin{array}{c}0 \\
(0)\end{array}$ & $\begin{array}{c}23 \\
(52.27)\end{array}$ & $\begin{array}{c}20 \\
(45.45)\end{array}$ & $\begin{array}{c}1 \\
(2.27)\end{array}$ & 2.50 \\
\hline & $\sum f$ & 3 & 85 & 118 & 14 & $\mathrm{~T} ; 220$ \\
\hline & $\sum \%$ & 1.36 & 38.63 & 53.63 & 6.36 & T: 99.98 \\
\hline
\end{tabular}

Pre-service Teachers' English Language Skills in Peer Teaching

Table 2 shows that the participants were worried about their English language skills and became more nervous when they made errors $(M=2.84)$. This means that even if they tried to speak English well, no matter how hard they tried, they still got nervous when they made errors. Next, English pre-service teachers were also afraid if they did not know how to teach certain grammatical rules $(M=2.89)$. The highest mean score of this aspect was $(M=3.91)$, which indicated that the participants were afraid of not having good enough English like their peers.

Table 2:

Perceptions of English Pre-service Teachers' Language Skills in Peer Teaching

\begin{tabular}{|c|c|c|c|c|c|c|}
\hline No. & Statements & $\begin{array}{l}\text { SA } \\
F(\%)\end{array}$ & $\begin{array}{c}\text { A } \\
F(\%)\end{array}$ & $\begin{array}{c}\text { D } \\
F(\%)\end{array}$ & $\begin{array}{l}\text { SD } \\
F(\%)\end{array}$ & Mean \\
\hline 6. & $\begin{array}{l}\text { Not worried when explaining the } \\
\text { lesson in English. }\end{array}$ & $\begin{array}{c}3 \\
(6.82)\end{array}$ & $\begin{array}{c}18 \\
(40.90)\end{array}$ & $\begin{array}{c}20 \\
(45.45)\end{array}$ & $\begin{array}{c}3 \\
(6.82)\end{array}$ & 2.52 \\
\hline 7. & $\begin{array}{l}\text { Not worried when explaining } \\
\text { advanced vocabulary. }\end{array}$ & $\begin{array}{c}1 \\
(2.27)\end{array}$ & $\begin{array}{c}10 \\
(22.73)\end{array}$ & $\begin{array}{c}31 \\
(70.45)\end{array}$ & $\begin{array}{c}2 \\
(4.55)\end{array}$ & 2.77 \\
\hline 8. & $\begin{array}{l}\text { Not afraid of not knowing how to } \\
\text { teach certain grammatical rules. }\end{array}$ & $\begin{array}{c}0 \\
(0)\end{array}$ & $\begin{array}{c}7 \\
(15.90)\end{array}$ & $\begin{array}{c}28 \\
(63.64)\end{array}$ & $\begin{array}{c}9 \\
(20.45)\end{array}$ & 2.89 \\
\hline 9. & $\begin{array}{l}\text { Not became more nervous when } \\
\text { making errors. }\end{array}$ & $\begin{array}{c}1 \\
(2.27)\end{array}$ & $\begin{array}{c}10 \\
(22.73)\end{array}$ & $\begin{array}{c}28 \\
(63.64)\end{array}$ & $\begin{array}{c}5 \\
(11.36)\end{array}$ & 2.84 \\
\hline 10. & $\begin{array}{l}\text { Not afraid of not having good } \\
\text { English as another peers. }\end{array}$ & $\begin{array}{c}1 \\
(2.27)\end{array}$ & $\begin{array}{c}7 \\
(15.91)\end{array}$ & $\begin{array}{c}31 \\
(70.45)\end{array}$ & $\begin{array}{c}5 \\
(11.36)\end{array}$ & 2.91 \\
\hline & $\sum f$ & 6 & 52 & 138 & 24 & $\mathrm{~T}: 220$ \\
\hline & $\sum \%$ & 2.72 & 23.63 & 62.72 & 10.91 & $\mathrm{~T}: 99.98$ \\
\hline
\end{tabular}


These findings reveal that the mastery of English language skills affected their anxiety. This clarified Pasaribu and Herendita's (2018) finding that English pre-service teachers were worried about their lack of English mastery. The participants said their realization of others' better English language skills made them afraid, insecure and worried. The qualitative data obtained from the interview clarified this finding, as indicated in the following excerpts.

"I was a little bit afraid because the others' English skills were good. But I told to myself, instead of being afraid when someone else has better English than me, I will motivate myself to be good, too." (Interviewee C)

"What made me afraid was when I saw another people's English skills were better than me. It made me insecure and not confident to speak English so it affected my teaching performances" (Interviewee A)

\section{English Pre-service Teachers' Preparation in Peer Teaching}

As shown in Table 3, the participants were afraid of writing detailed lesson plan ( $M=$ 2.64.) They tended to be worried if the lesson plan was not good enough. Furthermore, they were also anxious of developing suitable sources/materials for the lessons $(\mathrm{M}=$ 2.66). They were, however, most worried if the lesson that they taught was not interested $(M=3.04)$.

Table 3:

Perceptions of English Pre-service Teachers' Preparation in Peer Teaching

\begin{tabular}{llccccc}
\hline \multirow{2}{*}{ No. } & \multicolumn{1}{c}{ Statements } & SA & A & D & SD & \multirow{2}{*}{ Mean } \\
\cline { 3 - 6 } & & $\mathrm{F}(\%)$ & $\mathrm{F}(\%)$ & $\mathrm{F}(\%)$ & $\mathrm{F}(\%)$ & \\
\hline 11. & Not getting more nervous if preparing more & 3 & 27 & 14 & 0 & 2.25 \\
& for English class. & $(6.82)$ & $(61.36)$ & $(31.82)$ & $(0)$ & \\
\hline 12. & Not anxious about maintaining a good & 1 & 16 & 27 & 0 & 2.59 \\
& enough standard of preparation. & $(2.27)$ & $(36.36)$ & $(61.36)$ & $(0)$ & \\
\hline 13. & Not afraid of writing detailed lesson plan. & 1 & 18 & 21 & 4 & 2.64 \\
& & $(2.27)$ & $(40.91)$ & $(47.73)$ & $(9.09)$ & \\
\hline 14. & Not anxious of developing suitable & 1 & 14 & 28 & 1 & 2.66 \\
& sources/materials for the lessons. & $2.27)$ & $(31.82)$ & $(63.64)$ & $(2.27)$ & \\
\hline 15. & Not worried if the lesson is not interesting. & 0 & 6 & 30 & 8 & 3.04 \\
& & $(0)$ & $(13.64)$ & $(68.18)$ & $(18.18)$ & \\
\hline & $\sum f$ & 6 & 81 & 120 & 13 & $\mathrm{~T}: 220$ \\
\hline & $\sum \%$ & 2.73 & 36.82 & 54.54 & 5.91 & $\mathrm{~T}: 100$ \\
\hline
\end{tabular}

From this aspect, most participants were worried about not having enough preparation because they wanted to give interesting lesson to the students. The participants said that they had tried to prepare as good as possible, especially the lesson plan. For them, the lesson plan is the most important thing to prepare. This was in line with Oparah, Nwoke, and Ikwuanusi (2017) who posited that "teaching practice enabled the pre-service teachers to understand how to write lesson plan, so it might reduce the anxiety of writing the good lesson plan." The information obtained from the interview clarified this. 
"First, I prepared the lesson plan. I chose the method and learning media that can make the students enjoy studying with me. Second, I prepared the materials clearly. Last, I prepared myself and my mental. I trained myself in front of the mirror to speak" (Interviewee D).

"The preparations that I made was well enough, I think. I even talked to myself in front of the mirror to practice my speaking skill. And then, I made sure about the materials that I want to deliver can be full and understood by the students." (Interviewee E).

\section{English Pre-service Teachers' Lesson Delivery in Peer Teaching}

As shown in table 4, the participants were afraid if they could not deliver abstract concept to their peers $(M=2.82)$. Then, they feared if their peers did not pay close attention when they delivered the lessons $(M=2.84)$. Finally, they were afraid if they did not meet the goals of the lesson plan when teaching $(\mathrm{M}=2.89)$. From this category we can see that pre-service English teachers have had their best effort to write the lesson plan. So, if they did not meet the goal of the lesson plan, they felt that the teaching was failed.

Table 4:

Pre-service English Teachers' Lesson Delivery in Peer Teaching

\begin{tabular}{|c|c|c|c|c|c|c|}
\hline No. & Statements & $\begin{array}{c}\text { SA } \\
F(\%)\end{array}$ & $\begin{array}{c}\mathbf{A} \\
\mathrm{F}(\%)\end{array}$ & $\begin{array}{c}\text { D } \\
F(\%)\end{array}$ & $\begin{array}{c}\text { SD } \\
F(\%)\end{array}$ & Mean \\
\hline 16. & $\begin{array}{l}\text { Not worried when introducing new } \\
\text { topics to the peers. }\end{array}$ & $\begin{array}{c}2 \\
(4.55)\end{array}$ & $\begin{array}{c}28 \\
(63.64)\end{array}$ & $\begin{array}{c}12 \\
(27.27)\end{array}$ & $\begin{array}{c}2 \\
(4.55)\end{array}$ & 2.32 \\
\hline 17. & $\begin{array}{l}\text { Not afraid of not being able to deliver } \\
\text { abstract concept to peers. }\end{array}$ & $\begin{array}{c}1 \\
(2.27)\end{array}$ & $\begin{array}{c}10 \\
(22.73)\end{array}$ & $\begin{array}{c}29 \\
(65.91)\end{array}$ & $\begin{array}{c}4 \\
(9.09)\end{array}$ & 2.82 \\
\hline 18. & $\begin{array}{l}\text { Not feared of not getting the peers' } \\
\text { attention when delivering the lessons. }\end{array}$ & $\begin{array}{c}0 \\
(0)\end{array}$ & $\begin{array}{c}12 \\
(27.27)\end{array}$ & $\begin{array}{c}27 \\
(61.36)\end{array}$ & $\begin{array}{c}5 \\
(11.3 \\
6)\end{array}$ & 2.84 \\
\hline 19. & $\begin{array}{l}\text { Not feared of not meeting the goals of } \\
\text { the lesson plan when teaching. }\end{array}$ & $\begin{array}{c}1 \\
(2.27)\end{array}$ & $\begin{array}{c}7 \\
(15.91)\end{array}$ & $\begin{array}{c}32 \\
(72.73)\end{array}$ & $\begin{array}{c}4 \\
(9.09)\end{array}$ & 2.89 \\
\hline 20. & $\begin{array}{l}\text { Not afraid of not being able to give } \\
\text { appropriate feedback to the peers. }\end{array}$ & $\begin{array}{c}1 \\
(2.27)\end{array}$ & $\begin{array}{c}10 \\
(22.73)\end{array}$ & $\begin{array}{c}30 \\
(68.18)\end{array}$ & $\begin{array}{c}3 \\
(6.82)\end{array}$ & 2.79 \\
\hline & $\sum f$ & 5 & 67 & 130 & 18 & $\mathrm{~T}: 220$ \\
\hline & $\sum \%$ & 2.27 & 30.45 & 59.09 & 8.18 & $\mathrm{~T}: 99.99$ \\
\hline
\end{tabular}

These findings also revealed that the participants believed the great importance of getting students' attention in order to achieve the goals. This was in line with Merc's (2011) finding that many pre-service teachers noted that they could meet the success levels they expected when they could get the students' attention. The qualitative data obtained from the interview clarified these findings, as indicated in the following excerpts.

"When I did my teaching practice, the existence of my lecturer made me so nervous and anxious. Even if I made my preparation well, I was afraid of making mistakes or delivering the materials wrong to the students. But I could manage it by immediately clarifying the mistakes I have made." (Interviewee E) 
"I think, the thing that made me most nervous and anxious was the thought of my students about my teaching. Also, when I saw my students' face while I was teaching that showed that they were not interested made me more nervous. I managed it by taking a deep breath and continuing my teaching." (Interviewee B)

\section{Peers' Condition in Peer Teaching}

Table 5 shows that most of the participants were anxious if their peers were unable to follow the lessons $(\mathrm{M}=2.82)$. They were also anxious about possible problems in the class with individual learners' misbehaviour $(\mathrm{M}=2.84)$. The highest mean score from this aspect is the point that the participants were anxious when their peers asked difficult questions $(M=2.86)$. If explaining the lesson made them nervous, answering their peers' difficult questions made them more anxious. The information obtained from the interview clarified this.

"At first, the condition was conducive. The students paid attention to me and listened to me. But a few minutes later, some of them made a noise like disturbing his or her friends. By the noise that they made, I felt anxious." (Interviewee D).

"The students paid attention to my teaching and did well for all the assignments. It made me less anxious about not being respected." (Interviewee A).

Table 5:

Peers' Condition in Peer Teaching

\begin{tabular}{|c|c|c|c|c|c|c|}
\hline No. & Statements & $\begin{array}{c}\text { SA } \\
\mathrm{F}(\%)\end{array}$ & $\begin{array}{c}\mathbf{A} \\
\mathrm{F}(\%)\end{array}$ & $\frac{\mathbf{D}}{\mathrm{F}(\%)}$ & $\begin{array}{c}\text { SD } \\
\mathrm{F}(\%)\end{array}$ & Mean \\
\hline 21. & $\begin{array}{l}\text { Not anxious about possible problems } \\
\text { in the class with individual learners' } \\
\text { misbehavior. }\end{array}$ & $\begin{array}{c}1 \\
(2.27)\end{array}$ & $\begin{array}{c}7 \\
(15.91)\end{array}$ & $\begin{array}{c}34 \\
(77.27)\end{array}$ & $\begin{array}{c}2 \\
(4.54)\end{array}$ & 2.84 \\
\hline 22. & $\begin{array}{l}\text { Not anxious of not being respected in } \\
\text { the classroom. }\end{array}$ & $\begin{array}{c}3 \\
(6.82)\end{array}$ & $\begin{array}{c}12 \\
(27.27)\end{array}$ & $\begin{array}{c}24 \\
(54.54)\end{array}$ & $\begin{array}{c}5 \\
(11.36)\end{array}$ & 2.70 \\
\hline 23. & $\begin{array}{l}\text { Not anxious when peers ask difficult } \\
\text { questions. }\end{array}$ & $\begin{array}{c}1 \\
(2.27)\end{array}$ & $\begin{array}{c}9 \\
(20.45)\end{array}$ & $\begin{array}{c}29 \\
(65.91)\end{array}$ & $\begin{array}{c}5 \\
(11.36)\end{array}$ & 2.86 \\
\hline 24. & $\begin{array}{l}\text { Not anxious about how to give each } \\
\text { learner the attention to each peer's } \\
\text { needs. }\end{array}$ & $\begin{array}{c}2 \\
(4.54)\end{array}$ & $\begin{array}{c}14 \\
(31.82)\end{array}$ & $\begin{array}{c}25 \\
(56.82)\end{array}$ & $\begin{array}{c}3 \\
(6.82)\end{array}$ & 2.66 \\
\hline 25. & $\begin{array}{l}\text { Not anxious if the peers were unable } \\
\text { to follow the lessons. }\end{array}$ & $\begin{array}{c}2 \\
(4.54)\end{array}$ & $\begin{array}{c}10 \\
(22.73)\end{array}$ & $\begin{array}{c}26 \\
(59.09)\end{array}$ & $\begin{array}{c}6 \\
(13.64)\end{array}$ & 2.82 \\
\hline & $\sum f$ & 9 & 52 & 138 & 21 & $\mathrm{~T}: 220$ \\
\hline & $\sum \%$ & 4.09 & 23.63 & 62.73 & 9.54 & $\mathrm{~T}: 99.99$ \\
\hline
\end{tabular}

\section{English Pre-service Teachers' Evaluations in Peer Teaching}

As shown in Table 6, the participants were worried if they could not pass the practicum $(M=2.70)$. And then, there were two highest mean score in this aspect, because there were two categories that reached same mean score. The first finding showed that preservice English teachers felt anxious when they were observed and evaluated by the supervisors while teaching $(M=2.82)$. And the second showed that they were anxious with the expectations of the supervisors $(M=2.82)$. This can be concluded that they were afraid if they could not meet with their supervisors' expectations. This was in line with Rieg, Paquette, and Chen's (2007) argument that teachers' high expectation 
contributed a factor to their anxiety. The information obtained from the interview clarified this.

"All in all, my teaching practice was great. My teaching and my students were good. As the evaluation, I learned that being too anxious was not good. So, if I made mistakes, I just need to calm down and do not need to panic." (Interviewee C).

"I was so nervous at first. I thought about how if my students are smarter than me, how if my students do bad things to me, how if they don't like me? Well, it was just my over thinking. At the end, it turned out that my teaching was pretty satisfying." (Interviewee D).

Table 6:

Pre-service English Teachers' Evaluations in Peer Teaching

\begin{tabular}{|c|c|c|c|c|c|c|}
\hline No. & Statements & $\begin{array}{c}\text { SA } \\
F(\%)\end{array}$ & $\begin{array}{c}\text { A } \\
F(\%)\end{array}$ & $\begin{array}{c}\text { D } \\
F(\%)\end{array}$ & $\begin{array}{l}\text { SD } \\
F(\%)\end{array}$ & Mean \\
\hline 26. & $\begin{array}{l}\text { Not worried about not passing the } \\
\text { practicum. }\end{array}$ & $\begin{array}{c}2 \\
(4.54)\end{array}$ & $\begin{array}{c}12 \\
(27.27)\end{array}$ & $\begin{array}{c}27 \\
(61.36)\end{array}$ & $\begin{array}{c}3 \\
(6.82)\end{array}$ & 2.70 \\
\hline 27. & $\begin{array}{l}\text { Not anxious about being observed and } \\
\text { evaluated by the supervisors while } \\
\text { teaching. }\end{array}$ & $\begin{array}{c}2 \\
(4.54)\end{array}$ & $\begin{array}{c}8 \\
(18.18)\end{array}$ & $\begin{array}{c}30 \\
(68.18)\end{array}$ & $\begin{array}{c}4 \\
(9.09)\end{array}$ & 2.82 \\
\hline 28. & $\begin{array}{l}\text { Not anxious with the supervisors' } \\
\text { expectation. }\end{array}$ & $\begin{array}{c}2 \\
(4.54)\end{array}$ & $\begin{array}{c}9 \\
(20.45)\end{array}$ & $\begin{array}{c}28 \\
(63.64)\end{array}$ & $\begin{array}{c}5 \\
(11.36)\end{array}$ & 2.82 \\
\hline 29. & $\begin{array}{l}\text { Not feeling anxious when being observed } \\
\text { by peers. }\end{array}$ & $\begin{array}{c}3 \\
(6.82)\end{array}$ & $\begin{array}{c}15 \\
(34.09)\end{array}$ & $\begin{array}{c}26 \\
(59.09)\end{array}$ & $\begin{array}{c}0 \\
(6.82)\end{array}$ & 2.52 \\
\hline 30. & $\begin{array}{l}\text { Not anxious when the lecturer gave a verbal } \\
\text { evaluation of the teaching in front of the } \\
\text { peers. }\end{array}$ & $\begin{array}{c}3 \\
(6.82)\end{array}$ & $\begin{array}{c}16 \\
(36.36)\end{array}$ & $\begin{array}{c}24 \\
(54.54)\end{array}$ & $\begin{array}{c}1 \\
(2.27)\end{array}$ & 2.52 \\
\hline & $\sum f$ & 12 & 60 & 13 & 13 & $\mathrm{~T}: 220$ \\
\hline & $\sum \%$ & 5.45 & 27.27 & 61.36 & 5.91 & T: 99.99 \\
\hline
\end{tabular}

Pre-service English Teachers' Classroom Management in Peer Teaching

The data in Table 7 shows that the participants were worried if they had to enforce discipline to their peers, since the peers were their own classmates $(M=3.09)$. They were also anxious if they were not able to have the full control of the class $(M=3.14)$. They were afraid if their peers would think if they were not real teachers, so they did not have to be respected. The highest mean score was $M=3.23$ concerns with the participants' anxiety about the time that they had. They were afraid if they did not have enough time to deliver the materials. This was in line with Başaran \& Aksu's (2005) idea that "to manage classrooms effectively, the best way to guarantee and sustain classroom order is to develop student self-control since enabling them to control themselves create opportunities for a disciplined and well-ordered classroom." The interview had shown the students' perception as follows:

"I told my students to pay attention to me. They did. But, when I had games to play, the students were so noisy even before I explained how to play it. They 
talked to each other and it made me a bit mad. But eventually, I could control them." (Interviewee B).

"I managed the classroom by asking my students to pay attention to me. I also enforced discipline to my students. At first, I was worried if they don't respect me, but in the end I realized that they did respect me." (Interviewee $\mathrm{E}$ ).

Table 7:

Pre-service English Teachers' Classroom Management in Peer Teaching

\begin{tabular}{|c|c|c|c|c|c|c|}
\hline No. & Statements & $\begin{array}{c}\text { SA } \\
\mathrm{F}(\%)\end{array}$ & $\begin{array}{c}\text { A } \\
F(\%)\end{array}$ & $\frac{\text { D }}{\mathrm{F}(\%)}$ & $\begin{array}{c}\text { SD } \\
\mathrm{F}(\%)\end{array}$ & Mean \\
\hline 31. & $\begin{array}{l}\text { Not anxious of not having the full control } \\
\text { of the class. }\end{array}$ & $\begin{array}{c}1 \\
(2.27)\end{array}$ & $\begin{array}{c}4 \\
(9.09)\end{array}$ & $\begin{array}{c}27 \\
(61.36)\end{array}$ & $\begin{array}{c}12 \\
(27.27)\end{array}$ & 3.14 \\
\hline 32. & $\begin{array}{l}\text { Not worried when teaching English } \\
\text { because the classes were crowded. }\end{array}$ & $\begin{array}{c}1 \\
(2.27)\end{array}$ & $\begin{array}{c}10 \\
(22.73)\end{array}$ & $\begin{array}{c}28 \\
(63.64)\end{array}$ & $\begin{array}{c}5 \\
(11.36)\end{array}$ & 2.84 \\
\hline 33. & $\begin{array}{l}\text { Not worried if cannot manage the time to } \\
\text { deliver the materials. }\end{array}$ & $\begin{array}{c}0 \\
(0)\end{array}$ & $\begin{array}{c}3 \\
(6.82)\end{array}$ & $\begin{array}{c}28 \\
(63.64)\end{array}$ & $\begin{array}{c}13 \\
(29.54)\end{array}$ & 3.23 \\
\hline 34. & $\begin{array}{l}\text { Not feeling uncomforTable with the noise } \\
\text { level in the class. }\end{array}$ & $\begin{array}{c}1 \\
(2.27)\end{array}$ & $\begin{array}{c}12 \\
(27.27)\end{array}$ & $\begin{array}{c}27 \\
(61.36)\end{array}$ & $\begin{array}{c}4 \\
(9.09)\end{array}$ & 2.77 \\
\hline 35. & $\begin{array}{l}\text { Not worried to enforce discipline to the } \\
\text { students. }\end{array}$ & $\begin{array}{c}0 \\
(0)\end{array}$ & $\begin{array}{c}6 \\
(13.64)\end{array}$ & $\begin{array}{c}28 \\
(63.64)\end{array}$ & $\begin{array}{c}10 \\
(22.73)\end{array}$ & 3.09 \\
\hline & $\sum f$ & 3 & 35 & 138 & 44 & $\mathrm{~T}: 220$ \\
\hline & $\sum \%$ & 1.36 & 15.91 & 62.73 & 20 & $\mathrm{~T}: 100$ \\
\hline
\end{tabular}

\section{CONCLUSIONS AND SUGGESTIONS}

Based on the results and discussions, it can be concluded that most of the participants felt anxious when they did the peer teaching practice. Even if some of them felt quite sure and relaxed when they were on the way to the classroom, but when it came to face the students and start teaching, they were nervous. The causes of that anxiety were their confidence, English skills, preparation, lesson delivery, students' condition, evaluation, and classroom management. Most of the participants in this study agreed that they experienced anxiety while teaching. As inexpert teachers, they were a little unconfident with their own teaching performance. The supervisor's expectations and their expectation as well emerged more pressure which can increase the anxiety level. Since English is not their first language, they were also anxious about not being able to master the English language skills. Other cogent factors that affected their anxiety were concerned with not being able to get students' attention, to make the lesson interesting, and to manage the condition of the students and the classroom. The findings revealed that the three major factors affecting the participants' anxiety are: English language skills, peers' condition, and classroom management. It was also revealed that too much anxiety can affect the teaching performance of pre-service English teachers' first encounters with the students.

This study only involved pre-service teachers of the same major from a single university. The data were collected through a questionnaire and open-ended questions at one point in time only. Therefore, the results may be valid only to students with the same study program; they cannot be generalized to other students in other institutions. Thus, future studies are recommended to conduct researches in the same area with a larger number of participants from different universities and with more various majors. 


\section{REFERENCES}

Başaran, S. T., \& Aksu, M. (2005). Effectiveness of Anatolian Teacher High Schools in terms of serving their intended purpose. European Journal of Educational Research, 19 (2), 54 - 78.

Billson, J. M., and R. G. Tiberius. (1991). Effective social arrangements for teaching and learning. In College teaching: From theory, to practice, ed. E.J. Menges and M. D. Svinicki, 87-109. New Directions for Teaching and Learning, 45 (Spring). San Francisco: Jossey-Bass

Cambridge. (2012). Anxiety Retrieved May, 2019 from http://dictionary.cambridge.org/dictionary/british/anxiety_1?q=anxiety.

Forsyth, D. R., and McMillan, J. H. (1991). Practical proposals for motivating students. In College teaching: From theory to practice, ed. R. J. Menges and M. D. Svinicki. New Directions for Teaching and Learning 45 (Spring). San Francisco: Jossey-Bass

Horwitz, E. K. (1996). Even teachers get the blues: Recognizing and alleviating language teachers' feelings of foreign language anxiety. Foreign Language Annals, vol 29(3), page 365-372.

Howarth, P., 2002, "Teachers and Stress 1", Modern English Teacher, 11(2), pp.56.

Ivanova, I., \& Skara-Mincāne. (2016). Development of professional identity during teacher's practice. Procedia - Social and Behavioral Sciences, 232, pp. 529-536.

Iwasiw CL, Goldenberg D. (1993). Peer teaching among nursing students in the clinical area: effects on student learning. $J$ Adv Nurs, 18:659-668.

Johnson, J. \& Perry, F. (1967). Readings in student teaching: For those who work with students. IOWA: WM. C. Brown Co. Inc

Kfouri, C. A (2013), Pre-service teachers and teacher education. Retrieved May 2019 from https://doi.org/10.1016/j.sbspro.2013.10.117

Kim, S. Y. and Kim, J. H. (2004). "When the Learner Becomes a Teacher: Foreign Language Teaching Anxiety as an Occupational Hazard", English Teaching, Vol. 59, No. 1, pp. 165.

Kongchan, C. and Singhasiri, W. (2008). "Teacher's Anxiety about Using L2 in EFL Classrooms", The $16^{\text {th }}$ Annual Korea TESOL International Conference: Responding to a Changing World, 25-26 Oct. 2008, Seoul, Korea, pp. 145-149.

Lee, J. (2019), A raining project to develop teachers' assessment literacy. Retrieved May 2019 from https://www.igi-global.com/chapter/a-training-project-todevelop-teachers-assessment-literacy/217145

Manion L, Keith RB, Morrison K \& Cohen L. (2003). A guide to teaching practice. Retrieved May 2019 from http//www books.google.com/books.

McKeachie, W. J. (1986). Teaching Tips: A guide book for the beginning college teacher. Massachusetts: Heath.

Merç, A. (2004), Reflections of pre-service EFL teachers throughout their teaching practicum: What had been good? What has gone wrong? What has changed? Master's degree, ELT, Graduate School of Education, Anadolu University.

Moskowitz, G., (1978). Caring and Sharing in the Foreign Language Class. Massachusetts: Newbury House.

Ohata, K. (2005). Language Anxiety from the Teacher's Perspective: Interview with Seven Experienced ESL/EFL Teachers, Journal of Language and Learning, 3(1), pp. 143. 
Murray-Harvey, R. (1999). Under stress: The concerns and coping strategies of teacher education students. Paper presented at Colloquium in field based education Flinders University, Adelaide.

Ngidi D.P \& Sibaya P.T. (2003). Student teacher anxieties related to practice teaching. South African Journal of Education, 23:18-22. Republic of South Africa. (2000). Norms and Standards for Educators. Government Gazette, No. 20844.

Oparah, J. S., Nwoke, B., Ikwuanusi, E. N. (2017), Influence of teaching practice exercise on pre-service teachers' professional development. IOSR Journal of Research \& Method in Education (IOSR-JRME)

Pardede, P. (2018). Mixed Methods Research Designs in EFL In: PROCEEDING English Education Department Collegiate Forum (EED CF) 2015-2018. Jakarta: UKI Press. pp. 230-243. Retrieved May 2019 from http://repository.uki.ac.id/view/creators/Pardede=3A Parlindungan=3A=3A.html

Pasaribu, T. A. and Harendita M. E. (2018), English language anxiety of pre-service teachers: Causes and coping strategies. LLT Journal: A Journal on Language and Language Teaching, Vol. 21, No. 2, pp. 134-147.

Perry R. (2004). Teaching practice for early childhood. A guide for students. Available at http://www Routledge.com catalogues./0418114838.pdf. Accessed May 20, 2019.

Randall, M. and Thornton, B. (2001). Advising and supporting teachers, Cambridge University Press, Cambridge, pp. 99-100.

Rieg, S. A., Paquette, K. R., \& Chen, Y. (2007). Coping with stress: An investigation of novice teachers' stressors in the elementary classroom [Electronic version]. Education, 128(2), 201-226.

Sammephet, B. \& Wanphet, P., (2013). Pre-service teachers' anxiety and anxiety management during the first encounter with students in EFL classroom. Journal of Education and Practice. 4(2), 78-87.

Scovel, T. (1991). The effect of affect on foreign language learning: a review of the anxiety research in E. K. Horwitz and D. J. Young. Englewood Cliffs, NJ: Prentice Hall

Oxford, R. L. (1989). Anxiety and the language learner: New insight. Language Learning vol. 39 no. 2.

Sukmadinata, N. S. (2004), Landasan psikologi proses pendidikan. Bandung: PT. Remaja Rosdakarya

Whitman, Neal A.; Fife, Jonathan D., Ed. (1998). Peer teaching: To teach is to learn twice. ASHE-ERIC higher education report No. 4, 1988. Office of Educational Research and Improvement (ED), Washington, DC.

Yuksel, I. (2008). Pre-service teachers' teaching anxiety: Its reasons and coping strategies. Proceedings of the IASK international conference: Teaching and learning 2008. 